\title{
The Relation Between BMI and Polypharmacy with Urinary Incontinence in Diabetic Geriatric Patients
}

\section{Diyabetik Geriyatrik Hastalarda VKİ ve Polifarmasinin Üriner İnkontinans ile İlişskisi}

\author{
Gulcin Sahingoz Erdal' ${ }^{1}$, Feyzi Sinan Erdal $^{2}$ (D)
}

${ }^{1}$ Department of Oncology, University of Health Sciences, Dr. Sadi Konuk Training and Research Hospital, Istanbul, Turkey

${ }^{2}$ Department of Urology, University of Health Sciences, Haseki Training And Research Hospital, Istanbul, Turkey

Cite as: Erdal GS, Erdal FS. The relation between BMI and polypharmacy with urinary incontinence in diabetic geriatric patients. Grand J Urol 2021;1(1):14-7.

Submission date: 12 December 2020

Acceptance date: 27 December 2020

Online first: 28 December 2020

Publication date: 20 January 2021

Corresponding Author: Feyzi Sinan Erdal / University of Health Sciences, Haseki Training And Research Hospital, Department of Urology, Istanbul, Turkey drsinanerdal@hotmail.com ORCID: 0000-0002-3248-7664

\begin{abstract}
Objective: In our study, we aimed to examine the effects of body mass index (BMI) and multiple drug use on urinary incontinence (UI) in diabetic geriatric patients.

Materials and Methods: Our study included 246 type 2 diabetes mellitus patients aged 65 and over who applied to our outpatient clinic between October and December 2019 and remained after the exclusion criteria were applied. The relationship between the frequency of UI and age, diabetes age, HbAlc, BMI, number of drugs and gender was investigated. UI described as any involuntary incontinence complaint. The questionnaire contained socio-demographic questions and the International Consultation on Incontinence Modular Questionnaire Urinary Incontinence Short Form (ICIQ-UI SF).

Results: Most (82.2\%) of the patients with UI were women. Diabetes age and HbA1c level did not differ significantly between those with and without UI. There was a statistically significant relationship between BMI and the number of drugs used with the indication of UI (Mann-Whitney U; $p<0.05$ ). Incontinence was more common in those with high BMI (average BMI $30.27 \mathrm{~kg} / \mathrm{m}^{2}$ ). While $47.7 \%$ of those with UI were obese patients. The number of drugs used was found significantly higher in those patients with UI $(\mathrm{p}=0.008)$.

Conclusion: UI causes social isolation, depressive mood and introversion. In our study, we found that obesity and polypharmacy are associated with incontinence and triggered urinary incontinence. This indicates that UI is a problem that needs to be questioned and focused on in this patient population.
\end{abstract}

Keywords: urinary incontinence, polypharmacy, geriatric patients, diabetes mellitus

Öz

Amaç: Çalışmamızda diyabetik geriyatrik hastalarda vücut kitle indeksi (VKİ) ve çoklu ilaç kullanımının üriner inkontinans (ÜI) üzerine olan etkilerini incelemeyi amaçladık.

Gereç ve Yöntemler: Çalışmamıza 2019 yılı ekim ve aralık ayları arasında polikliniğimize başvuran ve dışlama kriterleri uygulandıktan sonra kalan 246 tip 2 diabetes mellitus tanılı 65 yaş ve üzeri hasta dahil edilmiştir. Hastalarda Üİ sıklığı ile yaş, diyabet yaşı, HbA1c, VKİ, ilaç sayısı ve cinsiyet arasındaki ilişki araştırılmıştır. Üİ, herhangi bir istemsiz inkontinans şikayeti olarak tanımlandı. Anket, sosyo-demografik soruları ve Uluslararası İnkontinans Modüler Soru Formu Üriner İnkontinans Kısa Formunu (ICIQ-UI SF) içermekte idi.

Bulgular: Üİ olan hastaların \%82,2'si kadınlardan oluşmaktaydı. Diyabet yaşının ve HbA1c düzeylerinin inkontinansı olanlarda ve olmayanlarda anlamlı bir farklılığı yoktu. Üİ’e göre VKİ ve ilaç sayısı açısından istatistiksel anlamlı farklılık vardı (Mann-Whitney U p<0,05). İnkontinans, VKİ yüksek olanlarda daha sık görülmektedir. (VKİ ortalama 30,27). İnkontinansı olanların \%47,7 si obezdi. Kullanılan ilaç sayısı da inkontinansı olanlarda anlamlı olarak daha fazlayd $1(\mathrm{p}=0,008)$.

Sonuç: Geriatrik popülasyonda yaşam kalitesi, Üİ ve frajilite iç içedir. Özellikle Üİ kişinin sosyal izolasyonuna, depresif duygu durumuna ve içe kapanmaya neden olmaktadır. Çalışmamızda obezitenin ve polifarmasinin inkontinans ile ilişkili olduğunu ve üriner inkontinansı tetiklediğini gördük. Bu da inkontinansın bu hasta populasyonunda sorgulanması ve üzerinde durulması gereken bir sorun olduğunu göstermektedir.

Anahtar Kelimeler: üriner inkontinans, polifarmasi, geriyatrik hastalar, diabetes mellitus 


\section{Introduction}

Urinary incontinence (UI) is a common symptom of varying severity that can affect women of all ages. Although urinary incontinence is not directly life threatening, it can seriously disrupt the physical, psychological and social life of individuals [1].

Unless UI is considered and questioned by patients as a natural consequence of aging, it is often shamed and hidden. Therefore, patients consult the doctor late and the existing discomfort becomes more severe [2]. One study showed that women with diabetes complain less about urinary incontinence to doctors [3].

Geriatric syndromes are clinical conditions common in older adults who share underlying causal factors that involve more than one system. These include a range of clinical conditions that do not fit into a separate disease category. Examples of geriatric syndromes are incontinence, cognitive impairment, delirium, falls, pressure ulcer, pain, weight loss, anorexia, functional decline, and depression [4]. UI affects quality of life and fragility in geriatric patients. With aging, the number of comorbid diseases increase and the number of drugs used causes polypharmacy. Polypharmacy results in many side effects and a decrease in quality of life in the geriatric population [5]. Polypharmacy and urinary incontinence are common in the geriatric population. Adverse drug effects are a concern in geriatric patients and should be considered in patients with urinary incontinence. Drug treatments may cause the emergence or aggravation of lower urinary tract symptoms. This should be kept in mind when there is a newly emerging UI [6]. Drugs that can cause or contribute to urinary incontinence in the elderly were presented by the 4th International Incontinence Consultation in 2009 [7]. There are many drugs that cause UI symptoms, and drugs used to treat heart failure may be associated with UI. For example, in the use of ACE inhibitors, drug-induced cough stress can cause UI. Diuretics frequently used by geriatric patients may cause incontinence due to higher urine volüme [6]. Increased body mass index (BMI) has been associated with many chronic diseases, including cancer. Incidence of UI also increases in obese patients [8].

In our study, we aimed to investigate the relationship between the incidence of UI with polypharmacy and BMI in diabetic geriatric patient population.

\section{Materials and Methods}

Local ethics committee approval was obtained prior to study (Approval Number: 2019/412). A total of 246 Type 2 DM patients aged 65 and over who admitted to our outpatient clinic between 1 October and 1 December 2019 were included in our study,. Patients under 65 years of age, those who were not diagnosed with Type $2 \mathrm{DM}$, who had an indwelling urinary catheter, urinary tract infection, and those who could not give consent were excluded from the study. In this prospective study, the relationship between the frequency of UI and age, diabetes age, $\mathrm{HbAlc}$, BMI, number of drugs and gender were investigated. UI was described as complaint of any type of involuntary incontinence . Regardless of the type, all types of incontinence were included in the study (urge, stress and a stress+urge urinary incontinence). Urinalyses were performed to exclude urinary tract infection in patients. The questionnaire contained socio-demographic questions and the International Consultation on Incontinence Modular Questionnaire-Short Form Turkish Version (ICIQ-UI SF) [9]. The current HbAlc values of the patients with type $2 \mathrm{DM}$ were recorded. The patients' weight and height was measured, and their BMIs were calculated (weight/height2). The patients were asked about the medications that they were regularly using and the total number of medications were recorded.

This study was approved by the Ethics of Committees of Dr. Sadi Konuk Training and Research Hospital, and in accordance with the Helsinki Declaration and its later amendments or comparable ethical standards.

\section{Statistical Analysis}

MedCalc Statistical Software version 12.7.7 (MedCalc Software bvba, Ostend, Belgium; http://www.medcalc.org; 2013) program was used for statistical analysis. Student's t test was used to compare two variables that were independent and compatible with normal distribution, and the comparison of two variables that were not compatible was made using the Mann Whitney U test. Chi-Square (or Fisher Exact test where appropriate) was used to examine the relationship between categorical variables.

\section{Results}

Our study included 246 type 2 DM patients aged 65 and over. Average ages were calculated as 72.4 and 71.3 years in the group with and without incontinence, respectively. Most $(82.2 \%)$ of the patients with UI were women. Drugs used in both groups in order of frequency were antihypertensives, oral antidiabetic drugs, insulin, acetylsalicylic acid, proton pump inhibitors and analgesics. Drug distribution was similar in both groups. Diabetes age and HbA1c level did not differ significantly between those with and without UI (13.4\% and $13.1 \%$, respectively, $p>0,05$ ). There is a statistically significant relationship between BMI and the number of drugs used with the indication of UI (Mann-Whitney U; $p<0.05$ ). UI was more common in those with high BMI. (average BMIs in incontinent and continent patients were $30.27 \mathrm{~kg} / \mathrm{m} 2$ and $28.2 \mathrm{~kg} / \mathrm{m} 2$, respectively). Also $47.7 \%$ and $2.8 \%$ of those with UI were obese and morbidly obese patients, respectively. The number of drugs used was found significantly higher in those patients with UI $(\mathrm{p}=0,008)$ (Table 1).

\section{Discussion}

Due to many important developments in the treatment of diseases, successful struggle against infectious diseases and improvement in living conditions, life expectancy is prolonged. Accordingly, the elderly population is increasing rapidly in our country as in the World [10]. Clinical conditions that we call "geriatric syndrome", which can impair quality of life and 
Table 1. Comparison of parameters according to incontinence status

\begin{tabular}{|c|c|c|c|c|c|c|}
\hline & & \multicolumn{2}{|c|}{$\begin{array}{c}\text { Continence } \\
n=139\end{array}$} & \multicolumn{2}{|c|}{$\begin{array}{c}\text { Incontinence } \\
\mathbf{n}=107 \\
\end{array}$} & $\mathbf{p}$ \\
\hline & & Mean \pm SD & D & Median (Min-Max) & $\begin{array}{l}\text { D } \\
\text {-Max) }\end{array}$ & \\
\hline \multicolumn{2}{|l|}{ Age } & \multicolumn{2}{|c|}{$\begin{array}{c}71.3 \pm 6 \\
70(65-94)\end{array}$} & \multicolumn{2}{|c|}{$\begin{array}{c}72.4 \pm 5 \\
71(63-86)\end{array}$} & 0348 \\
\hline \multicolumn{2}{|c|}{ Diabetes duration } & \multicolumn{2}{|c|}{$\begin{array}{c}13.1 \pm 8 \\
10(1-42) \\
\end{array}$} & \multicolumn{2}{|c|}{$\begin{array}{c}13.4 \pm 9 \\
13(1-40)\end{array}$} & 0.950 \\
\hline \multicolumn{2}{|l|}{ HbA1c \% } & \multicolumn{2}{|c|}{$\begin{array}{l}6.95 \pm 1,77 \\
6.4(5-17)\end{array}$} & \multicolumn{2}{|c|}{$\begin{array}{c}6.95 \pm 1.47 \\
6.5(5.2-15)\end{array}$} & 0.315 \\
\hline \multicolumn{2}{|c|}{ BMI kg/m² } & \multicolumn{2}{|c|}{$\begin{array}{c}28.2 \pm 3,7 \\
28(19,8-41.5)\end{array}$} & \multicolumn{2}{|c|}{$\begin{array}{c}30.2 \pm 4.2 \\
30(19-41.3)\end{array}$} & $<0.001^{*}$ \\
\hline \multicolumn{2}{|c|}{ Number of Drugs } & \multicolumn{2}{|c|}{$\begin{array}{c}4 \pm 2 \\
4(1-13) \\
\end{array}$} & \multicolumn{2}{|c|}{$\begin{array}{c}5 \pm 3 \\
5(1-13)\end{array}$} & 0.008 \\
\hline & & $\mathrm{n}$ & $\%$ & $\mathrm{n}$ & $\%$ & \\
\hline \multirow[t]{2}{*}{ Gender } & Female & 87 & 62.6 & 88 & 82.2 & $0.001 * *$ \\
\hline & Male & 52 & 37.4 & 19 & $1 . .8$ & \\
\hline \multirow[t]{4}{*}{$\begin{array}{l}\text { BMI } \\
\text { subtypes }\end{array}$} & Normal & 26 & 18.7 & 7 & 6.5 & $0.004 * *$ \\
\hline & Overweighted & 68 & 48.9 & 46 & 43.0 & \\
\hline & Obese & 44 & 31.7 & 51 & 47.7 & \\
\hline & Morbidly Obese & 1 & 0.7 & 3 & 2.8 & \\
\hline
\end{tabular}

Mann-Whitney U, *Student t, **Fisher's Exact, BMI: body mass index

increase morbidity and mortality, are common in elderly patients. UI is also a common geriatric disease. Quality of life, UI and fragility are intertwined in the geriatric population. Especially UI causes social isolation, depressive mood and introversion. In our study, we found that obesity and polypharmacy are significantly associated with UI [5].

Previously reported risk factors for UI in women are higher BMI, multiparity, smoking, lower physical activity, current postmenopausal hormone use, diuretics, hysterectomy, vascular disease, longer diabetes duration, and urinary tract infection [11-13]. We identified some of the same risk factors, only polypharmacy and BMI have an association between glycemic control and urinary incontinence. Our results support the presence of BMI as a potentially risk factor for UI. Type 2 diabetes increases incontinence by causing microvascular damage and neuropathy, such as pudendal nerve degeneration and bladder sensational impairment in time [14]. However, in our study, the effect of duration of diabetes on incontinence was not found to be significant. After diuretics, calcium channel blockers and tricyclic antidepressants were found to be the factors mostly causing incontinence. Beta- and alpha-stimulators were also quite common ( $9 \%$ and $8 \%$, respectively) [15]. In our study, the mean number of drugs used in the group with and without incontinence were $5 \pm 3$ and $4 \pm 2$, respectively and drug usage was significantly higher in the group with incontinence (p:0,008).

The level of glycemic control as measured by HbAlc is significantly associated with the risk of urinary incontinence. Each percentage increase in $\mathrm{HbAlc}$ is associated with a $34 \%$ increase in the risk of only stress incontinence after controlling for age and BMI [14]. Phelan et al [11] found an association between $\mathrm{HbAlc}$ and urinary incontinence among women; however, Lee et al [16] found that higher HbAlc was less associated with urinary incontinence. No significant relationship was found between UI and HbA1c in our study.

Our study has several limitations. Urinary incontinence is a self-reported complaint. HbA1c represents blood glucose levels in the previous 3 months and does not show the duration of disease or other diabetic complications. Therefore HbAlc does not capture longer-term glycemic control, which may affect urinary incontinence. Randomized controlled studies are needed to determine whether achieving glycemic control can improve urinary incontinence.

Despite these limitations, our study has several strengths. Our results are generalizable given the nationally representative sample used, and relatively limited number of missing data. Also validated questions were used to define urinary incontinence. 


\section{Conclusion}

Our study indicates that higher BMI levels and polypharmacy are significantly associated with the risk for urinary incontinence among elderly diabetic patients. Our results also suggest that there is a need for awareness concerning the risk of urinary incontinence among elderly women with diabetes.

Ethics Committee Approval: The study was approved by University of Health Sciences, Dr. Sadi Konuk Training and Research Hospital Ethical Committee, Bakirkoy, Istanbul, Turkey (Decision No: 2019/412).

Informed Consent: An informed consent was obtained from all the patients.

Publication: The results of the study were not published elsewhere in full or in part in the form of abstracts.

Peer-review: Externally peer-reviewed.

Authorship Contributions: Any contribution was not made by any individual not listed as an author. Concept - G.S.E., F.S.E.; Design - G.S.E., F.S.E.; Supervision - G.S.E., F.S.E.; Resources - G.S.E., F.S.E.; Materials - G.S.E., F.S.E.; Data Collection and/ or Processing - G.S.E., F.S.E.; Analysis and/or Interpretation - G.S.E., F.S.E.; Literature Search - G.S.E., F.S.E.; Writing G.S.E., F.S.E.; Critical Review - G.S.E., F.S.E.

Conflict of Interest: The authors declare that they have no conflict of interest.

Financial Disclosure: The authors have declared that they did not receive any financial support for the realization of this study.

\section{References}

[1] National Collaborating Centre for Women's and Children's Health (UK). Urinary Incontinence. London: RCOG Press; 2006.

[2] Hampel C, Wienhold D, Benken N, Eggersmann C, Thuroff JW. Prevalence and natural history of female incontinence. Eur Urol 1997;32:3-12.

[3] Doshi AM, Van Den Eeden SK, Morrill MY, Schembri M, Thom DH, Brown JS. Women with diabetes: Understanding urinary incontinence and help seeking behavior. J Urol 2010;184:1402-7. https://doi.org/10.1016/j.juro.2010.06.014.

[4] Bell SP, Vasilevskis EE, Saraf AA, Jacobsen JML, Kripalani S, Mixon AS, et al. Geriatric Syndromes in Hospitalized Older Adults Discharged to Skilled Nursing Facilities. J Am Geriatr Soc 2016;64:715-22. https://doi.org/10.1111/jgs.14035.

[5] Maher RL, Hanlon J, Hajjar ER. Clinical consequences of polypharmacy in elderly. Expert Opin Drug Saf 2014;13:57-65. https://doi.org/10.1517/14740338.2013.827660.

[6] Talasz H, Lechleitner M. Polypharmacy and incontinence. Z Gerontol Geriatr 2012;45:464-7.

https://doi.org/10.1007/s00391-012-0358-7.
[7] DuBeau CE, Kuchel GA, Johnson T, Palmer MH, Wagg A. Incontinence in the frail elderly: Report from the 4th international consultation on incontinence. Neurourol Urodyn 2010;29:165-78.

https://doi.org/10.1002/nau.20842.

[8] Hunskaar S. A systematic review of overweight and obesity as risk factors and targets for clinical intervention for urinary incontinence in women. Neurourol Urodyn 2008;27:749-57.

https://doi.org/10.1002/nau.20635.

[9] Cetinel B, Ozkan B, Can G. The validation study of ICIQSF Turkish version. Turk J Urol 2004;30:332-8.

[10] Türkiye İstatistik Kurumu Haber Bülteni Sonuçları 2017. https://data.tuik.gov.tr/Bulten/Index?p=Adrese-DayaliNufus-Kayit-Sistemi-Sonuclari-2016-24638 (accessed December 27, 2020).

[11] Phelan S, Kanaya AM, Subak LL, Hogan PE, Espeland MA, Wing RR, et al. Prevalence and risk factors for urinary incontinence in overweight and obese diabetic women: Action for Health in Diabetes (Look AHEAD) study. Diabetes Care 2009;32:1391-7.

https://doi.org/10.2337/dc09-0516.

[12] Dooley Y, Kenton K, Cao G, Luke A, Durazo-Arvizu R, Kramer H, et al. Urinary incontinence prevalence: Results from the National Health and Nutrition Examination Survey. J Urol 2008;179:656-61. https://doi.org/10.1016/j.juro.2007.09.081.

[13] Danforth KN, Townsend MK, Curhan GC, Resnick NM, Grodstein F. Type 2 Diabetes Mellitus and Risk of Stress, Urge and Mixed Urinary Incontinence. J Urol 2009;181:193-7. https://doi.org/10.1016/j.juro.2008.09.007.

[14] Wang R, Lefevre R, Hacker MR, Golen TH. Diabetes, Glycemic Control, and Urinary Incontinence in Women. Female Pelvic Med Reconstr Surg 2015;21:293-7. https://doi.org/10.1097/SPV.0000000000000193.

[15] Gormley EA, Griffiths DJ, McCracken PN, Harrison GM. Polypharmacy and its Effect on Urinary Incontinence in a Geriatric Population. Br J Urol 1993;71:265-9. https://doi.org/10.1111/j.1464-410X.1993.tb15940.x.

[16] Lee SJ, Karter AJ, Thai JN, Van Den Eeden SK, Huang ES. Glycemic control and urinary incontinence in women with diabetes mellitus. J Women's Heal 2013;22:1049-55. https://doi.org/10.1089/jwh.2012.4093. 